\title{
Fatherhood Models in the Middle Class of Contemporary Russia*
}

\author{
Alexandra Lipasova \\ PhD Student, Department of Sociology, National Research University Higher School of Economics \\ Address: Myasnitskaya str., 20, Moscow, Russian Federation 101000 \\ E-mail: alexandra.lipasova@gmail.com
}

\begin{abstract}
Drawing on in-depth interviews with married Russian fathers, this paper focuses on the gender contracts and fatherhood models of the middle class of contemporary Russia. It shows that while the ideal of fathers heavily involved in day-to-day parenting is widespread, the reality is somewhat different despite the active participation of Russian mothers in the labor market. Still, for most Russian men, fathering as a set of everyday practices of engaging with their children has more value than for the generation of their fathers. The research shows that modern Russian society can be characterized by the co-existence of egalitarian and traditional tendencies in gender relations. On the one hand, the practices of involved fathering are evolving, and on the other hand, the traditional patterns of masculinity are enforced, excluding fathers from the sphere of parenthood. Economic factors and rigid notions about the family gender contract are the main obstacles which prevent Russian men from "doing" involved fatherhood. The liberal phenomenon of "new fatherhood" which appeared in Western countries turned out to be much more conservative in Russia. The modern family is still the "space of struggle," and this struggle is counter-directed: it can be a fight for survival, or for power, or for an egalitarian gender order, against the discrimination of men as secondary parents, against old-fashioned traditional views on the father's and the mother's roles in the family, or for the preservation of those views.
\end{abstract}

Keywords: parenthood, fatherhood, masculinity, gender contract, involved fatherhood, fathering practices

\section{Background and Methodology}

The problematics of gender studies takes a prominent place in the field of modern social research. However, the discussion of gender problems is mainly focused on the understanding of the new role and place of women in society, and on the topic of work-life balance for women. The topic of fathers/fatherhood and fathering practices is less popular among researchers, which deepens traditional gender inequality in family relations and makes the role of the father seem secondary compared to that of the mother.

According to many authors, fatherhood in the Soviet past used to be a set of practices and concepts which pushed fathers to the providing and bread-winning spheres, but underestimated them as fathers. In some works, Soviet gender policy is described as discriminatory: parenthood was considered to be women's social liability and a sphere of men's deprivation (Chernova, 2007).

\footnotetext{
(c) Alexandra Lipasova, 2016

(C) Centre for Fundamental Sociology, 2016
}

DOI: $10.17323 / 1728-192 \mathrm{X}-2016-4-202-214$ 
A transition from a mainly state upbringing to a family one began to emerge in the new social conditions of the 9o's. According to S. Kukhterin, in the transition period of Russian history, a struggle to redefine family functions and gender relations was taking place in families. Men recognized that more was being demanded of them, but it was difficult to live up to their new role. Earning money in post-Soviet Russia required time and effort, while at the same time, many men were not used to participating in family life. Their wives, meanwhile, were socialized in a society in which women were expected to work, and the authority of their husbands was not taken too seriously. In this environment, it was not easy for Russian men to be respected as the heads of their families (Kukhterin, 2000).

Modern Russian society can be characterized by both egalitarian and traditionalistic tendencies in gender relations. On the one hand, we are facing the emergence of new interpretations and practices, while on the other hand, the strengthening of traditional patterns of masculinity and fatherhood is occurring. Formally speaking, there are no legislative barriers in the Russian Federation for the realization of "involved" fathering practices. In reality, though, men are constrained by the possibility of negative sanctions applied to them from their environment and employers, as well as by a common point of view existing in public discourse that "looking after children is not for real men."

Modern social conditions put women into a dependent-on-men position: they get maternity leave payment only for the first 1.5 years of a child's life, the shortage of kindergartens is extreme, the divorce rate is still high (60\% of marriages break up during the first 5 years, and every third child lives in a single-parent family), and many families do not get financial support (alimony) from the fathers (Russian Government, 2014).

The aims of this paper are to discover the main development tendencies of the institution of fatherhood in Russia, and to describe the basic features and characteristics of fatherhood models present in the middle class of contemporary Russia. The main goals of my research were to figure out the criteria of a father's efficiency, in what ways the present generation of fathers differs from the previous one, what gender contracts exist in contemporary families and what these contracts' advantages and disadvantages are, what fathering practices are present in families with different gender contracts and, finally, to determine if involved fatherhood exists in contemporary Russia.

The quantitative research on Russian families, their division of labor, and parenting styles is rather scarce. The only research project that could be turned to in order to investigate fathering practices existing in modern Russia is "Parents and children, men and women in family and society," namely its third wave of 2011 (Shalaginova, 2016). The path analysis of the data regarding married men with children under 14 (the total sample is 588 fathers) gives us several findings concerning their parental behavior:

- employed fathers tend to be more involved in playing with their children and spending their free time with them than unemployed ones;

- fathers who have more than one child are more likely to take them to kindergarten, school, and extra activities, as well as stay with them while they are ill, and help dress them, compared to men who have only one child; 
- men who have only sons are more eager to do homework with them, and help dress them than fathers who have both sons and daughters;

- men who live in cities are more likely to play, help dress their children, get them ready for bed, and make decisions about their future as compared to men from rural areas;

- more-educated men are more eager to take their children to school and do homework with them than their less-educated counterparts.

Obviously, this data is not enough to answer our research questions, so we turned to qualitative methods, namely the theme-centered, narrative-oriented interview. The advantages of this type of interview for this particular research are, firstly, the possibility to approach the topic from different methodological angles and, secondly, the possibility to combine the individual constructions of meaning and societal conditions (Scheibelhofer, 2005). In the context of the research topic, this method allows us-as far as it is feasible with a modest sample-to combine technological, value-emotional, and institutional angles of studying fathering practices of men at the levels of social structures, social dispositions, and individual meanings.

The number of interviews conducted with the representatives of middle class is 23 (10 with the representatives of the core middle class, and 13 respondents from the lower middle class). According to the recent research on social structure of modern Russian society, the core middle class comprises of managers, entrepreneurs, and professionals in all sectors of the economy, while the lower middle class consists of semi-professionals and service workers (Anikin, Tikhonova, 2016). The size of the sample was not defined in advance, and is constructed according to the principles of theoretical sampling (Strauss, Corbin, 2008). However, the number of interviews is in line with the directing principles of qualitative research which sets 15 interviews as a minimum sample size (Rozhdestvenskaya, 2012: 105). It is assumed that this size is essential to achieve the stage of "saturation" and comprises the number of sets of typical cases (the sample of typical cases) (Shteinberg, 2009). This principle is broadly represented in the foreign research of family practices, as it allows to show the variety of the existing patterns "without privileging one type of family as the norm" (Hertz, 2006).

One of the methodological constraints of this particular research was that I, being a woman, could not count on my male respondents to be completely sincere and open with me. For example, on several occasions, the fathers did not tell me that they got married after their partner became pregnant ("a marriage for good measure," as it is called in Russia, is commonly perceived as something improper), and I only realized it after studying their interviews more precisely. As Terry Arendell puts it, the respondents defended and proved their masculine identities in their interactions with a woman-interviewer (Arendell, 1997). Gender identity was a crucial issue in their narratives, and gender was both displayed and accomplished during our contacts (West, Zimmerman, 1987). This means that they were both presenting themselves as masculine persons, self-defined as being authoritative, competent, assertive, controlling and rational, and worked on proving their 
manhood in their conversations with me. I did not expect that the issue of their gender identity would be so significant in these interviews.

\section{Gender Contracts in Russian Families}

Each family has a so-called gender contract that sets the rules of interaction, rights, and obligations which define the gender division of labor in both the public and the private spheres, as well as responsible relations between men and women (Rotkirch, Temkina, 2007). In particular, the gender contract sets the principles according to which the family decides who and by what resources conducts the housework and family chores inside and outside the family. Based on normative notions of gender roles, men take on more of the provider role, while women take on more of the caregiver role, especially when children become part of the family unit. After the birth of a child, women are generally the "adapters", that is, the ones who change their work hours and schedules to suit their families. Eva Bernhardt argues that "Work and motherhood are incompatible precisely because work and fatherhood are perfectly compatible" (Bernhardt 1993: 36). Some research has shown that the contributions of men to domestic labor are positively related to countrylevel gender-egalitarian attitudes. For example, the Nordic countries display both a high gender equality value and high levels of paternal time spent with children, while at the other end of the scale, ex-communist Eastern European countries display a low level of gender equality and low levels of paternal time (Gauthier, DeGusti, 2012). Thus, the level of the father's involvement in child care practices can be regarded a as consequence of the existing gender order in the family: an egalitarian division of family labor forms a more active parental practices from the father's side, and vice versa.

The current research allowed for the defining of the following types of gender contracts in Russian middle-class families (Aboim, 2010):

(1) the male breadwinner model, in which the man provides for the family, and the woman is a housewife;

(2) dual earner/unequal carer (double shift for women): both partners work outside the household but the bulk of the housework and childcare is still conducted by the woman;

(3) dual earners/dual carer: the partners share the financial provision of the family, housework duties and nurturing of the children equally;

(4) female breadwinner-male helper/modified provider: a situation in which the woman takes the greater part of the responsibility of bread-winning, and the man takes an active participation in doing housework and looking after the children.

According to Sofia Aboim who analyzed data from the International Social Survey Programme (2002), the predominant gender contract present in Russian families is "dual earner/unequal carer" with different degrees of the housework load on women (65\%), followed by "male-breadwinner model" (19\%), and "dual earner/dual carer" arrangement (16\%) (Aboim, 2010: 102). Judging by this data set of 2002, the gender contract in which 
the woman took the bread-winner role was an anomaly and almost a non-existent situation. Referring to our qualitative data, we can argue that this is no longer the case.

The interviews show that the following gender contracts are typical for Russian middle class families:

- Core middle class: male breadwinner model or dual earner/unequal carer:

I absolutely didn't want her [my wife] to stay at home and do the housewife work, it was her who wanted it.

(Int. \#4 , 35 y.o., 2 children)

... it is going to be difficult to get back to the initial position, when she [my wife] goes back to work, I will have to take some of the housework... Initially she didn't want to stay at home all the time, she is not eager to be a housewife, she is interested in doing something of her own.

(Int. \#14 , 33 y.o., 1 child)

- Lower middle class: male breadwinner model or female breadwinner-male helper/ modified provider:

A girl must be beautiful and have a child. That's it, nothing more is required from her. It is the man who has to earn money. Basically, the woman doesn't have to work.

(Int. \#13, 27 y.o., 1 child)

The man must be strong, he makes decisions, leads his family and the woman follows him humbly.

$$
\text { (Int. \#16, } 34 \text { y.o., } 1 \text { child) }
$$

Eventually we happened to exchange our economic roles ... And due to it the mother's opinion became somewhat more authoritative in our family ... I came to live with it ... and besides my ambitions I have nothing to challenge it.

(Int. \#15, 44 y.o., 1 child)

The researchers of the new or intimate fatherhood point out that with the birth of children, men start to work more, and the length of time they spend in fathering work is not used by these men to evaluate the quality of their fathering. Additionally, fathers who spend relatively less time with their children do not express feelings of guilt about being worse fathers (Dermott, 2008). Employment is still considered the most socially appropriate form of successful masculinity. If a man, for some reason, stops being a breadwinner and provider (as in one of my interviews), he has to establish his status as the head of the family anew. It is much easier for many men to be a good father by financially providing for a family, since it is an important aspect of masculinity. As the interviews showed, the fulfillment of a breadwinner role can serve as an excuse for the types of employment which could be considered unsatisfactory and unacceptable in other circumstances (e.g., one of my respondents who is a graduate of one of the leading arts universities now works as a taxi-driver to provide for his family). 


\section{Fatherhood Models in Contemporary Russia}

Views on the normative roles of women and men in the family and the type of gender contract result in the fatherhood model and fathering practices. The interviews' analysis allows to define three main types of fatherhood models in contemporary Russia's middle class:

- The "Sunday dad" model, in which the father considers bread-winning as his most important responsibility. Parental roles are strictly gender-divided, and the father has the secondary role as the mother's helper in everyday childcare.

- The "available father" model, characterized by the father's reflexivity on his role in the family, his attempts to take on some "women's" tasks, the difficulties connected with those attempts, self-doubts of his competence, and the wish to be an active and responsible father.

- The "involved father" model, the main feature of which is a father's substantial participation in the everyday practices of care and nurturing, an equal division of parental duties, and a gender contract which satisfies both parties.

\section{"Sunday dad" model (male breadwinner)}

In this model, the fathers' involvement in caregiving, especially with young children, is a fraction of that undertaken by mothers. "Sunday dads" do spend time with their children, but it is dominated by play and leisure, while the mothers' time is more dominated by housework and care-taking tasks. The fathers' time with children is also more likely than the mothers' to be in the presence of the other spouse. There are a number of complex and interrelated reasons why this happens, including drawbacks of social policy, the workplace culture, and the wage gap between men and women. From the human capital theory perspective, the time allocated to children depends on the preferences and relative resources of the members of a given couple (Baizan et al., 2014). Thus, the partner with the higher resources (i.e., human capital or work experience) may be well prepared to bargain on the share and distribution of time spent with children. The group of the respondents whom I refer to as "Sunday dads" were usually higher-educated and much more ambitious than their wives. In this case, the low "bargaining power" of these women did not allow them to decrease their share of routine and supervisory activities with children, since these activities are less pleasant and rewarding for parents.

I assigned all the functions of family planning on her [his wife], and she is happy to do it, and I delegated these responsibilities to her.

(Int. \#7, 35 y.o., 4 children, core middle class)

We have a strict arrangement that my wife deals with the child. And I deal with earning money. She tried to talk it over, but I initially put it straight, it is useless to argue with me in this respect, I have enough problems at work.

(Int. \#13, 27 y.o., 1 child, lower middle class) 
I go to work when he [his son] is still asleep and come home when he is already asleep ... I am very well aware that I am no more than a Sunday dad.

(Int. \# 4 , 35 y.o., 2 children, core middle class)

\section{The "Available Father" Model (male breadwinner / equal earner/unequal carer)}

The respondents whom I labeled as "available fathers" produced more diverse and complicated narratives than their "Sunday" counterparts. On the one hand, these men tend to stress the mother's primacy in infant nurturing and care-giving:

Interviewer: What is your wife's job?

Respondent: Oh, she's got the most important job in the world-she is a mother.

(Int. \#1, 32 y.o., 1 child, core middle class)

As children grow out of infancy, this usually leads to a situation in which men help their wives by taking a share in primary childcare activities, i.e. developmental activities (face-to-face parent-child interactions, teaching something to a child, helping with homework, reading, playing, or talking with children), and high-intensity activities (faceto-face parent-child interactions related to physical care of the child, such as feeding, bathing, putting to bed, or taking care of the child when sick) (Baizán et al., 2014). However, fathers remain subordinate to their spouses who continue to make sure that everything is under control (Eerola, 2015). On the other hand, "available fathers" demonstrate a certain confusion about whether to be a "traditional" breadwinner who remains at some distance from the daily care-giving routines, or a "new" nurturer. They try to challenge the primacy of the mother, who often acts as a "gatekeeper," who always knows better, and prevents the father from learning parental caring skills (Fox, 2009). This striving towards more active and responsible fatherhood is especially typical of younger and moreeducated fathers.

In order to be a good father in my own eyes, I try to play with my child and choose the games that are useful, so that through the game he is directed not at idleness or useless things but something interesting. What my child is doing depends on what I am offering to him. I try to offer him something that is going to help and develop him and so on.

(Int. \#14 , 33 y.o., 1 child, core middle class)

\section{The "Involved Father" Model (equal earner / equal carer / female breadwinner-male helper/modified provider)}

As defined by James Pleck, father involvement has three core components:

- positive engagement (development-promoting activities with the child):

I trained him [his son] ... And then I helped him with the school subjects which he wasn't good at, and I had to work with him a lot. He finished school with a golden medal, and I think I deserve some credit for it.

(Int. \#15, 44 y.o., 1 child, lower middle class) 
- warmth and responsiveness:

My father never hugged or kissed me and I felt the need for it. I always hug and kiss my sons. My friends ask me: "Why do you kiss your boys? They won't grow up as real men ..." But I think it's important.

(Int. \#23, 30 y.o., 2 children, lower middle class)

- control, a multifaceted concept that includes monitoring, limit-setting, anticipating the child's needs, and participation in making important decisions about the children (Pleck, 2010):

We were watching her [his daughter] during the preparation for school, she liked mathematics, everything was $\mathrm{OK}$, but at the same time she likes various creative activities. Now she often brings "C"s for math, but "A"s or "A"s with a plus for literature reading. So she is a creative person and I see that she has stopped liking math. So I want to talk to my own first school teacher so she could tell me what psychological tricks I may use or something else, because it is sometimes difficult to convince Lisa [his daughter] to just sit and do math, she is distracting, dreaming or looking to the window.

(Int. \#8, 33 y.o., 1 child, core middle class)

Some research has shown that warmth and responsiveness, as well as control and monitoring, are significantly correlated with the frequency of positive engagement activities (Pleck et al., 2003).

The "involved fathers" turn out to be as capable as mothers with regard to children rearing, including the situation of "solo care," when the father provides nurturing to the child in the absence of his partner.

If she [his wife] is, say, busy with the younger daughter or doing something around the house, I am busy with the elder daughter ... If she has to go somewhere, I deal with the children, if I have to go-she is with the children. It is equality.

(Int. \#2, 28 y.o., 2 children, core middle class)

"Involved fathers" emphasize that their share in nurturing and caregiving is equal to that of the mother, and their shared parenthood is based on mutual spousal support. However, even for these fathers, the idea of gender equality does not go further than their family life. The interviews proved a hypothesis present in some research: involved fathers do not necessarily share egalitarian views on women's roles and rights in the public and private spheres. The realization of new fathering practices, the attitude to women's employment, and the division of the instrumental and expressive role in the family (according to T. Parsons) are not interconnected, but independent aspects of men's mentality (McGill, 2014). One can be an involved father and simultaneously demonstrate rigid views on women's rights for career self-fulfillment. 
Some of the respondents belonging to the available and involved fatherhood models turned out to be religious people with traditional or even patriarchal views on the preferred life trajectory of their daughters. Some research also shows that, for religious fathers, childcare is not a way of self-fulfillment, but a tool of preserving and transferring of family values. The father's active participation in his children's lives is not a sign of egalitarian family relations, but a means to strengthen existing family patterns (Johansson, Klinth, 2008).

Almost all respondents highlighted engagement in caring and responsible fatherhood in their own way. While the "involved fathers" are the closest to the concept of a new father, the idea of fathers as active parents was also present in the two other models.

\section{Past vs Present}

To analyze the continuity of parenthood values and fatherhood models, the respondents were asked to evaluate their own fathers' style of upbringing, and to try to formulate a symbolic message received from them. Very few respondents had no criticisms of their father's behavior. There were several patterns here:

- Denial/rejection of the father's way of life:

Due to him I know what I am never going to do. He didn't interfere in my life and I am grateful for that ... It is difficult to transfer something you know nothing about.

(Int. \#4, 35 y.o., 2 children, core middle class)

- Criticism of the father's behavior:

It seems to me he hasn't given me enough as a son, he should have given me a more masculine upbringing... Sons should be raised in a tougher way, you should even spank them, I think, beat them.

(Int. \#2, 28 y.o., 2 children, core middle class)

\section{- Total acceptance:}

Well, my father is my hero, I am following his path.

(Int. \#13, 27 y.o., 1 child, lower middle class)

- Choosing another member of the family as a role model (grandfather / elder brother / step-father):

My grandfather wasn't interested in wealth, he never gained anything either by career or relationships with people or money and he didn't want to, and probably I inherited that.

(Int. \#15, 44 y.o., 1 child, lower middle class) 
- Distrust to the mere idea of continuity:

I don't remember. Probably he just wanted me to study not to become an idler.

(Int. \#5, 32 y.o., 1 child, core middle class)

The relationship of my respondents with their fathers cannot be called an easy or warm one. For a long time, intimacy and emotions were not considered as an acceptable part of father-son interactions. Many generations of Russian men were raised to be tough, stable, and emotionally detached. On top of that, the previous generation of Russian fathers was brought up in a so-called "fatherless society," caused by World War II. Without a sustainable pattern of a father-figure in their childhood and adolescence, many Soviet fathers were unable to establish loving and respectful bonds with their sons.

So, as far as the symbolic message received from the previous generation of fathers is concerned, only a few respondents caught it and reflected on it. In many cases, it was not the father who served as a role model (as he was always at work / left the family / died young), but another male member of the family such as a grandfather, an elder brother, or a step-father.

\section{Discussion}

In general, the majority of the respondents pointed out that in the terms of fathering (i.e., direct childcare and the housework connected to it, or intensive time with children), parenthood for their fathers was not of a great value. In a way, modern fathers try to break this pattern though economic conditions and the necessity to constantly earn money stand in their way. The negative, narrow discourse of fatherhood left from the Soviet Russian past still influences the views and self-awareness of modern fathers.

We can conclude that the phenomenon of new fatherhood, which appeared in Western countries as a liberal one, put roots in another, rather traditional ground in Russia. Egalitarian views on the family gender contract, as expressed by the fathers belonging to the lower middle class, have the economic necessity of a double income coming from both parents as their first cause, and the mother's right for career self-fulfillment as the second priority.

Regardless of their employment status, women spend many more hours on housework than their male partners. This means that whether or not women are working outside the home, they are shouldering the bulk of the responsibility for keeping the household in order. Because our society attaches greater value and financial award to activities carried out in the public world, women's greater attachment to the home can limit both their status and economic resources. As a result, women's household responsibilities increase the likelihood that they will be in subordinate positions to their male partners.

When children are raised in a home environment in which women are subservient to men, they are more likely to accept these unequal gender roles (Larkin, 1997). Thus, the current gender order replicates itself. 
Our understanding of fatherhood is fundamentally bound to our understanding of a "man" as a gendered category. While many men still consider caring for children "sissy stuff" which should be done by women, we cannot speak about egalitarian relations in family life. Besides, not only men hold rigid views on gender roles in the family. Mothers, especially young ones, often act as "gatekeepers," and involuntarily deny the idea that their partners can be good nurturers. Nowadays, researchers talk about "aware parenthood" which implies a reflexive and active participation of both the mother and the father at each stage of planning, birth, and the up-bringing of a child. Using contraception, the decision to conceive a child, a pregnancy and childbirth, and the up-bringing of a child should be mutual spousal activities. With this approach, it is the pair who gives birth to a child, not only the mother. In this case, the child is planned and wanted, and both the mother and the father pay attention to him or her (Leshkevich, 2013).

In today's modern, fast-changing society, the traditional gender identity faces great challenges, while simultaneously, many gender norms and roles are becoming less rigid and more flexible. Many men feel uncomfortable when they compare their real self with the traditional norms of masculinity, which often were not transferred to them in their own family. Russian men are beginning to understand that it is impossible to solve many crucial problems with the old patriarchal means. The situation in modern society makes men use "feminine" practices, rethink their attitude to childcare, housework, and employment.

The modern family is still the "space of struggle," and this struggle is counter-directed. The struggle can be a fight for survival, for power, for an egalitarian gender order, against discrimination against men as secondary parents, against old-fashioned traditional views on the father's and the mother's roles in the family, or for the preservation of those views.

\section{References}

Aboim S. (2010) Plural Masculinities: The Remaking of the Self in Private Life, Farnham: Ashgate.

Anikin V., Tikhonova N. (2016) Professional'nyj portret srednego klassa i osobennosti ego jevoljucii [Professional Portrait of the Middle Class and the Peculiarities of Its Evolution]. Srednij klass v sovremennoj Rossii: opyt mnogoletnih issledovanij [The Middle Class in Contemporary Russia: The Experience of Many Years of Studies] (eds. M. Gorshkov, N. Tikhonova), Moscow: Ves' Mir, pp. 58-79.

Arendell T. (1997) Reflections on the Researcher-Researched Relationship: A Woman Interviewing Men. Qualitative Sociology, vol. 20, no 3, pp. 341-368.

Baizán P., Domínguez M., González M. J. (2014) Couple Bargaining or Socio-Economic Status? Why Some Parents Spend More Time with Their Children than Others. European Societies, vol. 16, no 1, pp. 3-27.

Bernhardt E. (1993) Fertility and Employment. European Sociological Review, vol. 9. no 1, pp. 25-42.

Chernova Z. (2007) Model' "sovetskogo" otcovstva: diskursivnye predpisanija [The Model of "Soviet" Fatherhood: Discursive Instructions]. Rossijskij gendernyj porjad- 
ok: sociologicheskij podhod [Russian Gender Order: Sociological Approach] (eds.

E. Zdravomyslova, A. Temkina), Saint Petersburg: EUSP Press, pp. 138-168.

Dermott E. (2008) Intimate Fatherhood: A Sociological Analysis, New York: Routledge.

Eerola P. (2015) Responsible Fatherhood: A Narrative Approach, Jyvaskyla: University of Jyvaskyla.

Fox B. (2009) When Couples Become Parents: The Creation of Gender in the Transition to Parenthood, Toronto: University of Toronto Press.

Gauthier A. H., DeGusti B. (2012) The Time-Allocation to Children by Parents in Europe. International Sociology, vol. 27, no 6, pp. 827-845.

Hertz R. (2006) Talking about "Doing" Family. Journal of Marriage and Family, vol. 68, no 4, pp. 796-799.

Johansson T., Klinth R. (2008) Caring Fathers: The Ideology of Gender Equality and Masculine Positions. Men and Masculinities, vol. 11, no 1, pp. 42-62.

Leshkevich A. (2013) Ot materinstva k osoznannomu roditel'stvu [From Motherhood to Aware Parenthood]. Gendernyj likbez [Gender FAQ] (eds. E. Mincheny, O. Sasunkevich), Vilnius: Belarusian House of Human Rights, pp. 69-80.

Kukhterin S. (2000) Fathers and Patriarchs in Communist and Post-Communist Russia. Gender, State and Society in Soviet and Post-Soviet Russia (ed. S. Ashwin), London: Routledge, pp. 71-89.

Larkin J. (1997) Sexual Harassment: High School Girls Speak Out, Toronto: Second Story Press.

McGill B. (2014) Navigating New Norms of Involved Fatherhood Employment, Fathering Attitudes, and Father Involvement. Journal of Family Issues, vol. 35, no 8, pp. 10891106.

Pleck J. H. (2010) Paternal Involvement: Revised Conceptualization and Theoretical Linkages with Child Outcomes. The Role of the Father in Child Development (ed. M. E. Lamb), Hoboken: John Wiley \& Sons, pp. 58-85.

Pleck J. H., Masciadrelli B. P. (2003) Paternal Involvement: Levels, Sources, and Consequences. The Role of the Father in Child Development (ed. M. E. Lamb), Hoboken: John Wiley \& Sons, pp. 222-270.

Rotkirch A., Temkina A. (2007) Sovetskie gendernye kontrakty i ih transformacija v sovremennoj Rossii [Sovet Gender Contracts and Their Transformation in Modern Russia]. Rossijskij gendernyj porjadok: sociologicheskij podhod [Russian Gender Order: A Sociological Approach] (eds. E. Zdravomyslova, A. Temkina), Saint Petersburg: EUSP Press, pp. 169-200.

Rozhdestvenskaya E. (2012) Biograficheskij metod v sociologii [The Biographical Method in Sociology], Moscow: HSE.

Russian Government (2014) Koncepcija gosudarstvennoj semejnoj politiki v Rossijskoj Federacii na period do 2025 goda. Rasporjazhenie Pravitel'stva RF ot 25.08.2014 N 1618-r [The Concept of State Family Policy in the Russian Federation for the Period to 2025. Edict of Government of the Russian Federation of 25.08.14 No 1618-r]. Available at: https://clck.ru/9Ua4L (accessed 12 April 2016). 
Scheibelhofer E. A. (2005) Reflection Upon Interpretive Research Techniques: The Problem-Centered Interview as a Method for Biographic Research. Narrative, Memory and Everyday Life (eds. N. Kelly, Ch. Horrocks, K. Milnes, B. Roberts, D. Robinson), Huddersfield: University of Hoddersfield, pp. 19-32.

Shalaginova I. (2016) Fenomen vovlechennogo otcovstva v Rossii [The Phenomenon of Involved Fatherhood in Russia] (MA thesis), Moscow: HSE.

Shteinberg I., Shanin T., Kovalev Y., Levinson A. (2009) Kachestvennye metody: polevye social'nye issledovanija [Qualitative Methods: Field Social Research], Moscow: Aleteya.

Strauss A., Corbin J. (2008) Basics of Qualitative Research: Techniques and Procedures for Developing Grounded Theory, London: SAGE.

West C., Zimmerman D. (1987) Doing Gender. Gender \& Society, vol. 1, no 2, pp. 125-151.

\title{
Модели отцовства в среднем классе современной России
}

\author{
Александра Липасова \\ Аспирантка департамента социологии Национального исследовательского университета \\ «Высшая школа экономики» \\ Адрес: ул. Мясницкая, д. 20, Москва, Российская Федерация 101000 \\ E-mail: alexandra.lipasova@gmail.com
}

В статье описываются гендерные контракты и модели отцовства в современном российском среднем классе. Приводятся результаты анализа глубинных интервью, на основании которых делается вывод о том, что для современных мужчин - представителей среднего класса отцовство носит бо́льшую ценность, чем для поколения их отцов. Показывается, что для современного российского общества характерно сосуществование эгалитарных и традиционалистских тенденций в гендерных отношениях: с одной стороны, наблюдается появление новых интерпретаций и практик, таких как вовлеченное отцовство, а с другой усиление традиционных образцов маскулинности и отцовства, исключающий отцов из сферы родительства. Распространению вовлеченного отцовства в России препятствуют экономические факторы и ригидные установки относительно внутрисемейного гендерного контракта. Отцы традиционного типа склонны дублировать ролевую модель поведения своих отцов. Явление «нового отцовства», возникшее на Западе как либеральное, в России легло на другую, скорее консервативную, почву. Эгалитарные установки относительно семейного гендерного контракта у отцов «нового» типа, принадлежащих к периферии ядра среднего класса, больше связаны с экономической необходимостью в доходе, поступающем от обоих родителей, чем с признанием права матери ребенка на карьерную самореализацию. Можно сказать, что негативный, «узкий» дискурс отцовства, оставшийся с советских времен, до сих пор влияет на самоощущение и мировоззрение отцов. Современная семья во многом остается «пространством борьбы», причем борьбы разнонаправленной - борьбы за выживание и за власть, борьбы за эгалитарный гендерный порядок, борьбы против дискриминации мужчин в сфере родительства и устаревших традиционных установок относительно ролей отца и матери или, наоборот, борьбы за сохранение этих установок.

Ключевые слова: родительство, отцовство, маскулинность, гендерный контракт, вовлеченное отцовство, отцовские практики 